\title{
An Identification of Teachers' Ability on Posing HOTS mathematics problems
}

\author{
Endah Budi Rahaju and Dini Kinati Fardah \\ Mathematics Department \\ Universitas Negeri Surabaya \\ Surabaya, Indonesia \\ endahrahaju@unesa.ac.id
}

\begin{abstract}
Higher-Order Thinking skills (HOTs) are needed to form our students to become more critical and creative individuals facing this sophisticated age. Teachers are required to be able to present learning that trains students to reason, think critically and creatively. This article presents the results of our research in the form of identifying the ability of teachers in compiling mathematical problems that requiring HOTs to solve. Seventeen teachers were trained in one-day workshops then given the opportunity to compile one HOTs problem in their own way. These problems were identified and categorized based on the topics, its compatibility with the criteria of assessing HOTs, and the category of cognitive processes and knowledge dimension according to Blooms' Taxonomy revised. The results showed that Numbers topic is mostly made by trainees $(47.06 \%)$. The most cognitive dimension shown by the teachers is analyzing $(47.06 \%)$. For the knowledge dimension, the problems posed by teacher are categorized as conceptual or procedural. Of all the participants, there were 1 person who still made mathematics problem that categorized as understanding level and 5 people who made problem that categorized as applying level.
\end{abstract}

Keywords-HOTs; mathematics problem; teachers' ability; problem posing

\section{INTRODUCTION}

Mathematics curriculum has been re-evaluated and needed to be developed as the world's demand changed these decades. Industry 4.0 issue has challenged teachers to prepare students more critical and creative to face this big data era. The ability to reason at higher levels is accepted and considered as a major instructional goal of education and is regarded as a motivating force behind efforts to reform education over the past two decades [1]. This has made the Higher-Order Thinking skill (Abbreviated as HOTs) of students needed to be developed so that our students will be flexible in facing the world changing. Though, teachers often find it difficult to make the transition from a traditional teaching-learning method that they know well to a method that develops HOTS [2]. It is because some educators have determined especially when standardized testing [3]. In accordance to this, a study of Mathematics Teachers' Level of Knowledge and Practice on the Implementation of Higher-Order Thinking Skills (HOTS) shows that the aspect of assessment was still at a nonsatisfactory level as compared to curriculum and pedagogy
[4]. It means that teacher may still have difficulties in designing learning or assessment that involving HOTs.

Higher-Order Thinking which is the ability to connect, manipulate, and transform the knowledge and experience that is already owned to think critically and creatively in an effort to determine decisions and solve problems in new situations is needed to be integrated into every $21 \mathrm{st}$ century subject learning. However, In fact, Indonesian students have not all had the opportunity to study mathematics by reasoning, creative thinking or critical thinking. Our teachers are still comfortable giving routine questions to their students. Teaching while developing HOTs is not a simple issue. To teach HOTS in an effective manner, a clear and accurate understanding of these skills is needed [5]. Therefore, some kinds of training or teachers development programs had to be utilized so that our will be more daring to give HOTs problems to their students. By joining these trainings, teachers' knowledge and understanding about how to design HOTs problem will be richer and their motivation to give HOTs problem to their students will increase.

The criteria to characterize Higher-Order thinking problems was based on the requirement to apply multiple stages to solve a problem for which no certain formula or pattern could be directly administered [6]. According to Bloom's Taxonomy, problem that require HOTs is in the intersection between knowledge dimension of conceptual, procedural, and metacognitive and cognitive process dimension of analyzing, evaluating and creating. The illustration is shown in the figure 1.

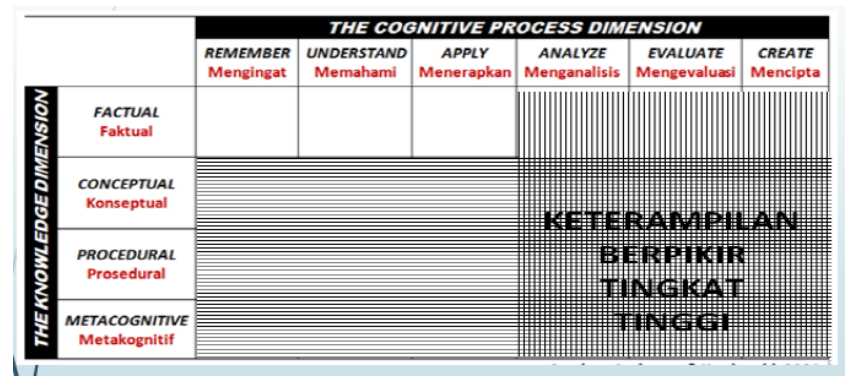

Fig. 1. The illustration of HOTS 
This paper combining those two resources to classified whether mathematics problem made by teachers after giving them one day workshop about constructing HOTs mathematical problem can be categorized as HOT problem or not.

\section{RESEARCH METHOD}

This is a qualitative research. This paper describe the research result descriptively. Seventeen secondary school mathematics teachers of Kediri Regency, Indonesia, were trained in a oneday workshop and given task in the end of the training. Teachers were given information about HOTs definition, how to assess HOTs, examples of HOT problem how to solve it, and how to generate HOT problems from routine problems. After question and answer session has ended, teachers were given a task to pose one problem that can be categorized as HOT problem of secondary school mathematics. These problems made by teachers then analyzed, identified, and classified as HOT problem or not by using Resnick and Bloom categorization as well as categorized based on the topics: algebra, numbers and pattern, geometry, statistics and probabilities according to Kisi-kisi Ujian Nasional SMP. Having HOT problems have been filtered, we identified further about which characteristics assessed by these problem and giving comment to the problems according to good question writing rules depending on the type of the question that teachers' made. Higher-Order Thinking skills that assessed by giving HOT problem to the students include the skill of: 1) transferring one concept to other concept; 2) Processing and applying information; 3) Finding a connection between some information given; 4) Using the information given to solve problem; and 5) study ideas and information critically. Generally, the method used in this research were analyzing, reducing data, coding, and making conclusion.

\section{RESULTS AND DISCUSSION}

Results of this research were divided into three main parts which are: 1) topics that selected by teachers; 2) classification of HOT problem including the cognitive process and knowledge dimension if it was categorized as HOT Problem; and 3) skill of HOT Problems that assessed.

\section{A. Topics Selection}

According to Kisi-kisi Ujian Nasional, the topics of mathematics subject in secondary school are algebra, number and pattern, geometry, and statistics \& probability. From the problem made by the teachers, topic selection distribution of those four are shown in the TABLE I.

TABLE I. TOPICS SELECTION

\begin{tabular}{|c|c|c|c|c|}
\hline Topics & Algebra & $\begin{array}{c}\text { Number \& } \\
\text { Pattern }\end{array}$ & Geometry & $\begin{array}{c}\text { Statistics \& } \\
\text { Probability }\end{array}$ \\
\hline $\begin{array}{c}\text { Number of } \\
\text { problem(s) }\end{array}$ & 5 & 8 & 4 & 0 \\
\hline $\begin{array}{c}\text { Percentage } \\
(\%)\end{array}$ & 29.41 & 47.06 & 23.53 & 0.00 \\
\hline
\end{tabular}

In the TABLE I, it can be seen that most of teachers, made problems of Number and Pattern (47.06\%). The number of problems in Algebra and geometry are in balance. However, none of those teachers pose statistics and possibility problem. It seems that HOT problem in this topic is still unfamiliar to the teachers. Teachers may lack ability in this topic, so that further research can be conducted.

\section{B. Classification of HOT problem, the cognitive process domain, and the knowledge domain.}

Problems that posed by teachers were analyzed and classified into HOT problems or not and then identified which cognitive process domain and the knowledge domain were match in. The classification and the percentage of the problem constructed were shown in TABLE II.

\section{TABLE II. PROBLEM CLASSIFICATIONS}

\begin{tabular}{|c|c|c|}
\hline Cognitive process domain & HOT problem & $\begin{array}{c}\text { Non-HOT } \\
\text { problem }\end{array}$ \\
\hline Recalling (\%) & & - \\
\hline Understanding (\%) & & 5.88 \\
\hline Applying (\%) & & 29.41 \\
\hline Analyzing (\%) & 47.06 & \\
\hline Evaluating (\%) & 17.65 & \\
\hline Creating (\%) & - & \\
\hline
\end{tabular}

From TABLE II, it is shown that $35.29 \%$ from the teachers were still confused the characteristics of HOT problem. From this percentage, $29.41 \%$ of the teachers still consider that the problems they posed is categorized as HOT problem though actually it is still in the lower level of HOT problem or exactly it is in the applying category. While problems in the analyzing category are mostly posed by teachers. Only one teacher that try to generate problem in the evaluating category. The example of problem made by teachers in each category will be discussed after.

1) Understanding categorized problem: In this category, only one teacher who posed the problem as shown in Fig 2.

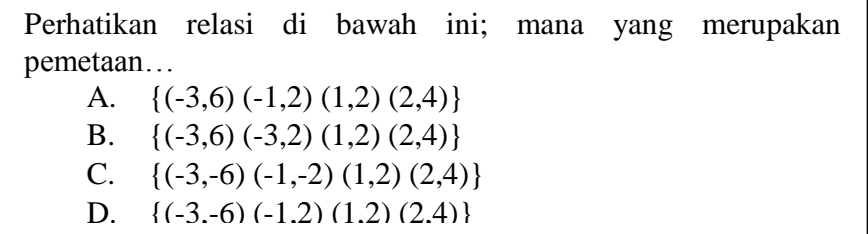

Fig. 2. Understanding categorized problem

From the Fig. 2 we can see that teacher only assess the student's conceptual understanding by asking which one the function between the relations given. By understanding the definition of function, students will answer the question easily. There is something interesting to be discussed in this example. We can see the option made by the teachers. All the options given are function except B, yet teacher give the correct answer which is C. It can be concluded that the teacher was having misconception about the definition of function.

2) Applying categorized problem: In this category, five teachers posed the proble. One of the problem is as shown in Fig 3. 
Ari, Banu dan Citra membeli penghapus dan penggaris di koperasi sekolah yang sama. Ari membeli satu penghapus dan tiga penggaris dengan membayar Rp 7.000. Banu membeli satu penghapus dan dua penggaris dengan membayar Rp 5000. Jika Citra membeli dua penghapus dan lima penggaris, maka jumlah uang yang harus Citra bayar adalah ...
A. Rp 10.000
B. $\quad$ Rp 11000
C. Rp 12000
D. Rp 13.000 .

Fig. 3. Applying categorized problem

In the Fig 3, it is shown that in solving the problems, student need to model the world problem into mathematics model and then try to solve it by applying method to get solution of two variables linear equation system then use the solution to get the unknown. There is no analysis process in this problem.

3) Analyzing categorized problem: This category is the most teachers used. There are seven teachers who made problems in this category. One of the problem is as shown in Fig 4.

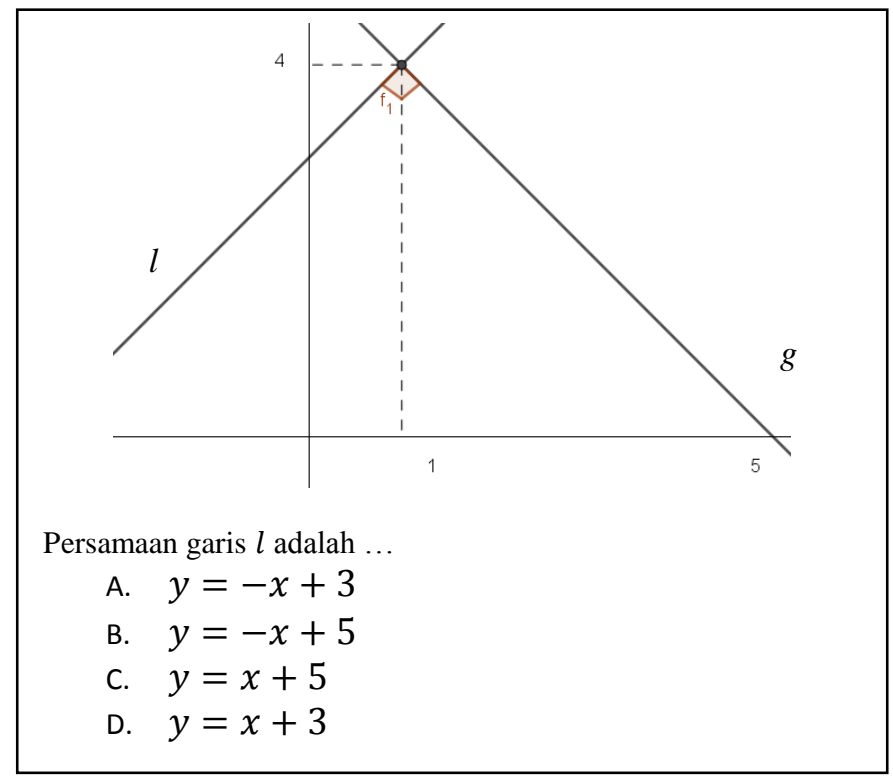

Fig. 4. Analyzing categorized problem

To solve problem in Fig.4, students need to study the information in the graphic critically. There are two lines which are perpendicular symbolized by the sign of right angle. One of them is given the absisca and ordinate of the intersection points with the other line, so that it is possible to determine the line equation. But, the other line (line $l$ ) only given the intersection point with the first line. If student does not investigate all the information in the figure given thoroughly including understanding the concept of two perpendicular line gradient, she/he cannot determine the equation of line $l$ correctly.
4) Evaluating categorized problem: This category is the highest level made by the teachers. There are three teachers who made problems in this category. One of the problem is imperfect as shown in Fig 5. And one of the two others is acceptable as shown in Fig. 6

Sebuah persegipanjang luasnya sama dengan luas sebuah persegi yang kelilingnya $24 \mathrm{~cm}$. tentukan ukuran persegipanjang tersebut agar memiliki luas terbesar.

Fig. 5. Evaluating categorized problem (imperfect one)

The type of problem in the Fig. 5 is different from the previous examples in term of question type. The example in the Fig.2, Fig.3 and Fig. 4 are multiple choices while the example in the Fig. 4 is essay question. Problem in fig. 5 is imperfect as mentioned above. The question should be "determine the dimension of the rectangle so that maximum perimeter can be obtained". The mistake has already confirmed to the teacher who posed this problem. This problem need analysis process to solve. Student need to make a relation between one topic to another. Concept of area is connected to concept of perimeter and the concept of square is connected to concept of rectangle. Student also needs to evaluate the dimension of the rectangle so that the maximum perimeter is obtained.

Ibu pergi ke sebuah toko membeli baju merek A dengan harga Rp 180.000,- dan diskon 10\%, baju merk B dengan harga Rp 200.000,- dan dua kali diskon 10\%+5\%. Manakah baju yang dipilih Ibu agar mendapat baju dengan harga yang lebih murah?

Fig. 6. Evaluating categorized problem

The problem in the Fig.6 is interesting since it is contextual in our daily life. Some people is often trapped by "big sale prank" of some department store. Without thinking critically, by seeing the " $10 \%+5 \%$ " sale, some people think that the price will be discounted $15 \%$. It did happened in our daily life. Usually, $10 \%$ wrote bigger than the $5 \%$. But for some people, they do not know and do not want to know what is the different. By managing the information, students will use their critical thinking to evaluate and judge which price is lower after the discount given. There are still many mistake in writing nominal symbol.

\section{Skill of HOT that assessed}

By analyzed the HOT problem posed by teachers, it can be identified which skill that can be assessed using those problems. From the results in table II, there is $47.06 \%$ of all teachers or exactly 8 of 17 teachers who posed analyzing categorized problem and $17.65 \%$ who posed evaluating categorized problem or exactly 3 of 17 teachers. The percentages of the skills that assessed by those 11 problems are shown in TABLE III.

TABLE III. SKILl OF HOT THAT ASSESSED

\begin{tabular}{|l|c|}
\hline \multicolumn{1}{|c|}{ Skills assessed } & Percentage (\%) \\
\hline Transferring one concept to other concept; and & 36.36 \\
\hline Processing and applying information; & 18.18 \\
\hline Finding a connection between some information given; & 9.09 \\
\hline Using the information given to solve problem & 18.18 \\
\hline Study ideas and information critically. & 18.18 \\
\hline
\end{tabular}


Transferring one concept to the other concept is mostly assessed by teachers utilizing the problem they posed $(36.36 \%)$. But this percentage is not significant with other skill that assessed. It need further research that using more samples to get more data to see the distribution clearly.

\section{CONCLUSION}

Giving task to the teachers to pose HOT problem we obtained some interesting results. There are still some teachers that confused to differentiate between applying categorized problems and analyzing, evaluating, or creating problems. Some teachers felt that the problems they made already in HOT level, but it is still in the applying categorized problem though No one try to pose problems that categorized as creating. It is not a simple issue generating problems that encourage students to create. There is no teacher who posed statistics and probability problems as well. For further workshop, there are two suggestion we can deliver. The first one, it can be suggested to design a training that help teachers designing HOT problems that categorized as creating. The second, it is suggested to develop the mathematical content knowledge of teachers especially in statistics and probability topic.

\section{ACKNOWLEDGMENT}

All this works are conducted as part of community service in Kediri Municipality and Kediri Regency by the Mathematics and Science Faculty of Universitas Negeri Surabaya, year 2018.

\section{REFERENCES}

[1] A. Costa, Developing minds: A resource book for teaching thinking (3rd ed.), Alexandria, Va.: Association for Supervision and Curriculum Development, 2010.

[2] A. Zohar, Higher-Order thinking in science classrooms: students' learning and teacher' professional development, Dordrecht, The Netherlands: Kluwer Academic Press, 2004.

[3] D. Ravitch, The death and life of the great American school system: How testing and choice are undermining education, New York: Basics Books, 2010.

[4] AH. Abdullah, M. Mokhtar, NDA. Halim, DF. Ali, LM. Tahir, and UHA. Kohar, EURASIA Journal of Mathematics Science and Technology Education. Vol 13, No 1, 2017, pp. 3-17

[5] D. Kuhn, Education for thinking, Cambridge, MA: Harvard University Press, 2005.

[6] L. Resnick, Education and learning to think. National Academy Press.Sadker, M. P. \& Sadker, D. M. (2000). Teachers, Schools, and $\begin{array}{llll}\text { Society. } & \text { New } & \text { York: } & \text { McGraw-Hill. }\end{array}$ 